\title{
Beijing University Efficiency Evaluation Based on DEA
}

\author{
ZHANG Yan-fang \\ Basic teaching department \\ Beijing University of Agriculture \\ Beijing 102206, China \\ zhangyanfang@bac.edu.cn
}

\author{
CHEN Xiao-xin \\ Basic teaching department \\ Beijing University of Agriculture \\ Beijing 102206, China \\ chen10145@sina.cn
}

\begin{abstract}
Based on the teaching and the scientific research data in 2000-2010, this paper utilizes DEA $\left(C^{2} R\right.$ and $\left.B C^{2}\right)$ model to evaluate the higher education resources allocation scale and effectiveness. The results show that, the University enrollment expansion in Beijing in 1999 had taken effect in 2001 and 2002. We evaluate and analysis the efficiency of teaching research in Beijing universities. Conclusion: University scientific research efficiency of Beijing has fluctuations. The paper points out that University can adjust the investment allocation of resources to increase output and improve the allocation of education resources DEA effective degree when they were in comprehensive efficiency invalid cases.
\end{abstract}

Keywords—DEA; universities; resources; efficiency; evaluate

\section{INTRODUCTION}

Universities in China have increased enrollment since the Ministry of Education formulated "Education Revitalization Action Plan Facing 21st Century" in $1999^{[1]}$. The number of college graduates amounted to 6.6 million in 2011, which is eight times more than the number of college graduates in 1998 (before university enrollment increase ${ }^{[2-3]}$. Meanwhile, gross enrollment rate of China's higher education has increased from approximately $10 \%$ before university enrollment to $24.2 \%$ in 2009 , indicating that nearly a quarter of the youth population are college graduates ${ }^{[4]}$. China has entered internationally recognized universal higher education phase. This is a big leap of social education system, which will inevitably lead to some new problems ${ }^{[1]}$, such as education quality decline caused by inadequate investment in education, difficult job hunting because of too many graduates and so on. Currently, studies on college graduates' employment difficulty due to the increased enrollment are the most ${ }^{[5-13]}$, and there are also some studies on the teaching quality problems caused by the increased enrollment ${ }^{[14-16]}$. It is worth noting that these educational issues are not all caused by university enrollment increase. In fact, China is increasing investment in education funding, teachers and other aspects every year. Therefore, how to make full use of the limited resources of universities and to improve the efficiency of running college is particularly important. As a multiple-input and multiple-output system, the relationship between input and output of universities is very complex, and each index is difficult to be measured by unified measuring unit. These features lead to greater difficulties in evaluating the efficiency of running colleges by using traditional cost- effectiveness analysis method. As data envelopment analysis (DEA) method has good inclusiveness for index, needs not to know the function relationship between input and output and is better able to avoid the influence of subjective factors, it is increasingly showing its advantages in dealing with efficiency evaluation issues of such multiple-input and multiple-output institution like universities ${ }^{[17]}$.

The application of DEA method in the field of education was relatively earlier, and in 1974, Levin had discussed the measuring method of technical efficiency of education production $^{[18-19]}$. In 1983, Bessent et al applied DEA method to evaluate the efficiency of relevant education programs[18-20]. With the gradual maturity of DEA method, more and more researchers began to apply this method to explore the inputoutput efficiency of universities. For example, Abbotta et al applied DEA method to analyze the input-output efficiency of Australian universities ${ }^{[18-21]}$. Flegg, Athanassopoulos et al applied DEA method to analyze the efficiency of Britain universities ${ }^{[18-22]}$. China's studies on the technical efficiency of universities of "985 Project" by applying DEA method are more, and there are also comparisons among the efficiency of universities across the country. The data of evaluation on the efficiency of Beijing universities still have not been found. As the capital, Beijing has numerous universities and is an important base to train high-level innovative talents, so it is necessary to study the running efficiency of universities in Beijing.

\section{EDEA INTRODUCTION}

A. Charnes and W. W. Cooper Professor, American operations researchers, first proposed DEA in 1978[23-24]. Based on relative efficiency, DEA applies mathematical programming model to evaluate the relative effectiveness or benefits between the data with multiple-index input and multiple-index output and the "unit" of the same type. It carries out multipleindex comprehensive evaluation of "relative advantages and disadvantages" of various sets of same samples according to a set of observations about multiple-input multiple-output. DEA has better inclusiveness for index, needs not to know the function relationship between input and output and is better able to avoid the influence of subjective factors. Annual input and output efficiency evaluation on Beijing Universities in this paper mainly uses the following two models: $C^{2} R$ model of 
constant scale returns, and $\mathrm{BC}^{2}$ model of variable scale returns ${ }^{[18,25,26,27]}$.

\section{ESTABLISHMENT OF INPUT-OUTPUT EFFICIENCY EVALUATION SYSTEM OF UNIVERSITIES}

Input-output study includes both aspects of research and teaching, and input-output indicator system is selected through repeated experiments to conduct calculations. All the data are from "Beijing Statistical Yearbook".

\section{A. Selecting Research Indicators}

To conduct effective analysis on resource allocation of universities requires the establishment of a scientific and rational evaluation indicator system of input-output efficiency.
To ensure the scientific nature of input-output efficiency evaluation and analysis, it is necessary to find out valuable indicators in the variety of input-output indicator system. The selection of indicator refers to literature ${ }^{[27]}$, and there are two principles in the literature: first, the indicator data should be easily accessible; second, the number of indicators should not be excessive. To make the evaluation more scientific, under the premise of considering the actual significance of each evaluation indicator, third principle is added in the selection, which is, trying to choose uncorrelated variables as input variables. The method is to conduct factor analysis on the input variables selected (Table 1) to determine its relevance. To conduct factor analysis on input variables, the factor scoring matrix after rotation is shown in Table 2.

TABLE I. INPUT VARIABLES

\begin{tabular}{|c|c|c|c|c|c|c|c|c|c|}
\hline $\begin{array}{l}\text { The Aver- } \\
\text { age Stu- } \\
\text { dents That a } \\
\text { Full-time } \\
\text { Teacher is } \\
\text { Responsible } \\
\text { for (person) }\end{array}$ & $\begin{array}{c}\text { School } \\
\text { Building } \\
\text { Area } \\
\text { (square } \\
\text { meters) }\end{array}$ & $\begin{array}{c}\text { Books } \\
\text { (ten thou- } \\
\text { sand) }\end{array}$ & $\begin{array}{c}\text { Number } \\
\text { of Staff } \\
\text { and } \\
\text { Teachers } \\
\text { (person) }\end{array}$ & $\begin{array}{l}\text { Full-time } \\
\text { Teachers } \\
\text { (person) }\end{array}$ & $\begin{array}{l}\text { Science } \\
\text { and } \\
\text { Technol- } \\
\text { ogy Per- } \\
\text { sonnel } \\
\text { (person) }\end{array}$ & $\begin{array}{l}\text { Science } \\
\text { and } \\
\text { Technol- } \\
\text { ogy } \\
\text { Funds } \\
\text { Raised } \\
\text { (ten thou- } \\
\text { sand yu- } \\
\text { an) }\end{array}$ & $\begin{array}{l}\text { Total } \\
\text { Educa- } \\
\text { tion In- } \\
\text { come } \\
\text { (ten } \\
\text { thousand } \\
\text { yuan) }\end{array}$ & $\begin{array}{l}\text { Total } \\
\text { Educa- } \\
\text { tion Ex- } \\
\text { penditure } \\
\text { (ten } \\
\text { thousand } \\
\text { yuan) }\end{array}$ & $\begin{array}{l}\text { Capital } \\
\text { Construc- } \\
\text { tion Ex- } \\
\text { penditure } \\
\text { (ten } \\
\text { thousand } \\
\text { yuan) }\end{array}$ \\
\hline$x_{1}$ & $x_{2}$ & $x_{3}$ & $x_{4}$ & $x_{5}$ & $x_{6}$ & $x_{7}$ & $x_{8}$ & $x_{9}$ & $x_{10}$ \\
\hline
\end{tabular}

TABLE II. FACTOR SCORING MATRIX AFTER ROTATION

\begin{tabular}{|c|c|c|c|c|}
\hline \multirow[b]{2}{*}{ Input Variables } & \multicolumn{4}{|c|}{ Main Factor } \\
\hline & 1 & 2 & 3 & 4 \\
\hline $\begin{array}{l}\text { Average Students That a Full-time Teacher } \\
\text { is Responsible for (person) } \boldsymbol{x}_{\mathbf{1}}\end{array}$ & -0.0757 & -0.94239 & -0.1773 & 0.005274 \\
\hline School Building Area (square meters) $\boldsymbol{x}_{2}$ & 0.534326 & 0.743377 & 0.328395 & 0.196959 \\
\hline Books (ten thousand) $\boldsymbol{x}_{3}$ & 0.751971 & 0.557732 & 0.338772 & -0.05459 \\
\hline Number of Staff and Teachers $\boldsymbol{x}_{\mathbf{4}}$ & 0.690265 & 0.613219 & 0.36514 & -0.04987 \\
\hline Full-time Teachers $\boldsymbol{x}_{\mathbf{5}}$ & 0.627353 & 0.695266 & 0.340921 & 0.060638 \\
\hline Science and Technology Personnel (person) $\boldsymbol{x}_{\mathbf{6}}$ & 0.939023 & 0.002309 & 0.086039 & -0.16141 \\
\hline Science and Technology Funds Raised (ten thousand yuan) $\boldsymbol{x}_{\mathbf{7}}$ & 0.538208 & 0.610287 & 0.552645 & -0.0066 \\
\hline Total Education Income (ten thousand yuan) $\boldsymbol{x}_{\mathbf{8}}$ & 0.845292 & 0.469407 & 0.176165 & -0.13887 \\
\hline $\begin{array}{l}\text { Total Education Expenditure } \\
\text { (ten thousand yuan) } \boldsymbol{x}_{\mathbf{9}}\end{array}$ & -0.14568 & 0.038831 & -0.03387 & 0.986134 \\
\hline Capital Construction Expenditure $\boldsymbol{x}_{\mathbf{1 0}}$ & -0.18101 & -0.27314 & -0.93475 & 0.046081 \\
\hline
\end{tabular}

As can be seen from Table 2, the load of input variables $x_{3}, x_{4}, x_{6}, x_{8}$ on the first main factor is large, so it is considered that the correlation among these three variables is strong, thus removing the variable $x_{4}$ and only retaining variables $x_{3}, x_{6}, x_{8}$; the load of input variables $x_{1}, x_{2}, x_{5}, x_{7}$ on the second main factor is large, thus removing the variable $x_{5}$, 
and only retaining variables $x_{1}, x_{2}, x_{7}$, and as education income $x_{8}$ is retained, input variables $x_{9}, x_{10}$ cannot be retained for reducing variables. The reason for this process lies in that the actual meaning of the four main factors is less obvious, so the main factors are not applied to replace each input variable to conduct evaluation. The indicator system obtained is shown as follows.

TABLE III. INDEX SySTEM OF EDUCATIONAL RESOURCES IN UNIVERSITIES OF BEIJING

\begin{tabular}{|c|c|c|c|c|c|c|c|c|}
\hline $\begin{array}{c}\text { Year(DMU } \\
\text { ) }\end{array}$ & $\begin{array}{l}\text { Students in } \\
\text { General } \\
\text { University } \\
\text { (per- } \\
\text { son) } \boldsymbol{y}_{\boldsymbol{1}}\end{array}$ & $\begin{array}{c}\text { Patent } \\
\text { Application } \\
\text { and Grant- } \\
\text { ed Quanti- } \\
\text { ty(item) } \\
\boldsymbol{y}_{\mathbf{2}}\end{array}$ & $\begin{array}{l}\text { Average } \\
\text { Students } \\
\text { That a Full- } \\
\text { time Teach- } \\
\text { er is Re- } \\
\text { sponsible } \\
\text { for (per- } \\
\text { son) } \boldsymbol{x}_{\mathbf{1}}\end{array}$ & $\begin{array}{l}\text { School Building } \\
\text { Area (square } \\
\text { meters) } \boldsymbol{x}_{\mathbf{2}}\end{array}$ & $\begin{array}{l}\text { Books (ten thou- } \\
\text { sand) } \boldsymbol{x}_{\mathbf{3}}\end{array}$ & $\begin{array}{c}\text { Science } \\
\text { and Tech- } \\
\text { nology } \\
\text { Personnel } \\
\text { (per- } \\
\text { son) } \boldsymbol{x}_{6}\end{array}$ & $\begin{array}{c}\text { Research and } \\
\text { Experiment } \\
\text { Development } \\
\text { Expendi- } \\
\text { ture(ten thou- } \\
\text { sand yuan) } \\
\boldsymbol{x}_{\mathbf{7}}\end{array}$ & $\begin{array}{l}\text { Total Education } \\
\text { Income (ten } \\
\text { thousand yu- } \\
\text { an) } \boldsymbol{x}_{\mathbf{8}}\end{array}$ \\
\hline 2000 & 282585 & 227 & 14.0 & 15994674.71 & 3619.628571 & 51988 & 102055.7 & 1437242 \\
\hline 2001 & 340284 & 240 & 17.0 & 17518637 & 4278.328571 & 51623 & 202011 & 1738872 \\
\hline 2002 & 398573 & 256 & 19.0 & 19042599 & 4829 & 50834 & 254050 & 2023516.4 \\
\hline 2003 & 458898 & 634 & 19.0 & 21309577 & 5209 & 53507 & 284929 & 2143365 \\
\hline 2004 & 500245 & 938 & 17.1 & 24271734 & 5676 & 45093 & 282867 & 2468461 \\
\hline 2005 & 536724 & 1112 & 17.0 & 25984502 & 6466 & 45295 & 357607 & 2642022.5 \\
\hline 2006 & 554702 & 1361 & 17.0 & 28594780 & 6806.18 & 49349 & 372514 & 3204994.9 \\
\hline 2007 & 567875 & 1801 & 15.4 & 28685115 & 7661 & 46988 & 476567 & 3808547 \\
\hline 2008 & 575639 & 2268 & 17.1 & 28975897 & 8025 & 49853 & 556812 & 4323684 \\
\hline 2009 & 577154 & 3397 & 16.5 & 29710334 & 8683.7 & 91337 & 700453 & 4825765 \\
\hline 2010 & 577828 & 4332 & 16.6 & 29805260 & 9218.1 & 93489 & 1101609 & 6032719 \\
\hline
\end{tabular}

\section{B. Analysis on the Results of Model Calculation}

- Evaluation Analysis on Teaching and Research

Results of the model calculation (Table 4) show: the overall efficiency of 2001, $2002(\mathrm{TE}=1)$ is invalid, pure technical efficiency $(\mathrm{PTE}=1)$ is valid, scale efficiency $(\mathrm{SE}<1)$ is invalid, and scale return is increasing ( irs). This shows that no investment needs to be reduced and no output can increase for the technical efficiency of universities in Beijing during these two years; the overall efficiency of the sample unit does not achieve effectiveness, because its size does not match its input and output; scale returns are increasing every day, so it is necessary to continue to expand the scale. Appropriately changing the proportion of investment, in order to achieve scale economy and scale merit of university.

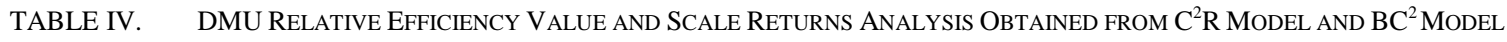

\begin{tabular}{|c|c|c|c|c|c|c|c|c|c|c|c|}
\hline DMU & 1 & 2 & 3 & 4 & 5 & 6 & 7 & 8 & 9 & 10 & 11 \\
\hline Year & 2000 & 2001 & 2002 & 2003 & 2004 & 2005 & 2006 & 2007 & 2008 & 2009 & 2010 \\
\hline $\begin{array}{c}\boldsymbol{C}^{2} \boldsymbol{R} \\
\text { Overall } \\
\text { Efficien- } \\
\text { cy TE } \\
\end{array}$ & 1.000 & 0.946 & 0.973 & 1.000 & 1.000 & 1.000 & 1.000 & 1.000 & 1.000 & 1.000 & 1.000 \\
\hline $\begin{array}{c}\boldsymbol{B} \boldsymbol{C}^{2} \text { Ove } \\
\text { rall Effi- } \\
\text { ciency } \\
\text { TE }\end{array}$ & 1.000 & 0.946 & 0.973 & 1.000 & 1.000 & 1.000 & 1.000 & 1.000 & 1.000 & 1.000 & 1.000 \\
\hline $\begin{array}{c}\text { Pure } \\
\text { Technical } \\
\text { Efficien- } \\
\text { cy PTE } \\
\end{array}$ & 1.000 & 1.000 & 1.000 & 1.000 & 1.000 & 1.000 & 1.000 & 1.000 & 1.000 & 1.000 & 1.000 \\
\hline $\begin{array}{c}\text { Scale } \\
\text { Efficien- } \\
\text { cy SE } \\
\end{array}$ & 1.000 & 0.946 & 0.973 & 1.000 & 1.000 & 1.000 & 1.000 & 1.000 & 1.000 & 1.000 & 1.000 \\
\hline $\begin{array}{c}\text { Returns } \\
\text { to Scale } \\
\text { RTS }\end{array}$ & - & irs & irs & - & - & - & - & - & - & - & - \\
\hline $\begin{array}{l}\text { Effec- } \\
\text { tiveness } \\
\text { of Over- } \\
\text { all Effi- } \\
\text { ciency }\end{array}$ & $\begin{array}{c}\text { DEA } \\
\text { Effective- } \\
\text { ness }\end{array}$ & $\begin{array}{c}\text { Non-DEA } \\
\text { Effective- } \\
\text { ness }\end{array}$ & $\begin{array}{c}\text { Non-DEA } \\
\text { Effective- } \\
\text { ness }\end{array}$ & $\begin{array}{c}\text { DEA } \\
\text { Effective- } \\
\text { ness }\end{array}$ & $\begin{array}{c}\text { DEA } \\
\text { Effective- } \\
\text { ness }\end{array}$ & $\begin{array}{c}\text { DEA } \\
\text { Effective- } \\
\text { ness }\end{array}$ & $\begin{array}{c}\text { DEA } \\
\text { Effective- } \\
\text { ness }\end{array}$ & $\begin{array}{c}\text { DEA } \\
\text { Effective- } \\
\text { ness }\end{array}$ & $\begin{array}{c}\text { DEA } \\
\text { Effective- } \\
\text { ness }\end{array}$ & $\begin{array}{c}\text { DEA } \\
\text { Effective- } \\
\text { ness }\end{array}$ & $\begin{array}{c}\text { DEA } \\
\text { Effective- } \\
\text { ness }\end{array}$ \\
\hline
\end{tabular}


Table 4 shows that the scale returns of 2001 should be increasing (irs). Conducting analysis on the input and output of 2001, Table 4 shows the technical efficiency of 2001 is 1.000 , and the scale efficiency is 0.946 (less than 1), indicating that no investment needs to be reduced and no output can increase for the technical efficiency of 2001; Table 5 shows the second unit (2001) has input redundancy, and insufficient output (not all are zero). Students in general university (person) $y_{1}$ have no insufficiency and redundancy in output, and patent application and granted quantity (item) $y_{2}$ has insufficient output, which should increase 1.426 items. In the first input factor, the average students that a full-time teacher is responsible for (person) $x_{1}$ reduce $0.008+0.505=0.513$, that is reducing from 17.000 to $17.000-0.513=16.487$, while the rest of the investment also reduce corresponding amount, thus the output of patent application and granted quantity (item) $y_{2}$ can be increased by 1.426 , that is, the output is $240.000+1.426=241.426$. It indicates that appropriately adjusting the input of various aspects, such as reducing the average students that a full-time teacher is responsible for (person) $x_{1}$, would make the school's research capacity (patent application and granted quantity (item) $y_{2}$ ) improved. Input and output of the third unit (2002) have no redundancy and insufficiency (both $S^{-}, S^{+}$are 0 ).

TABLE V. INPUT AND OUTPUT OF 2001, REDUNDANCY VALUE AND TARGET VALUE

\begin{tabular}{|c|c|c|c|c|}
\hline DMU & Original Value & Input Redundancy & Insufficient Output & Target Value \\
\hline $\begin{array}{l}\text { Students in General University (per- } \\
\text { son) } \boldsymbol{y}_{\mathbf{1}}\end{array}$ & 340284.000 & 0.000 & 0.000 & 340284.00 \\
\hline $\begin{array}{l}\text { Patent Application and Granted } \\
\text { Quantity(item) } \boldsymbol{y}_{\mathbf{2}}\end{array}$ & 240.000 & 0.000 & 1.426 & 241.426 \\
\hline $\begin{array}{l}\text { Average Students That a Full-time } \\
\text { Teacher is Responsible for (person) } \\
\boldsymbol{x}_{\mathbf{1}}\end{array}$ & 17.000 & -0.008 & -0.505 & 16.487 \\
\hline $\begin{array}{l}\text { School Building Area (square me- } \\
\text { ters) } \boldsymbol{x}_{\mathbf{2}}\end{array}$ & 17518636.860 & -7751.994 & 0.000 & 17510884.866 \\
\hline Books (ten thousand) $\boldsymbol{x}_{\mathbf{3}}$ & 4278.329 & -1.893 & -55.197 & 4221.238 \\
\hline $\begin{array}{l}\text { Science and Technology Personnel } \\
\text { (person) } \boldsymbol{x}_{\mathbf{6}}\end{array}$ & 51623.000 & -22.843 & -186.222 & 51413.935 \\
\hline $\begin{array}{c}\text { Research and Experiment Develop- } \\
\text { ment Expenditure(ten thousand } \\
\text { yuan) } \boldsymbol{x}_{\boldsymbol{7}}\end{array}$ & 2021.000 & -89.390 & -24255.354 & 177666.256 \\
\hline $\begin{array}{l}\text { Total Education Income (ten thou- } \\
\text { sand yuan) } \boldsymbol{x}_{\mathbf{8}}\end{array}$ & 1738872.000 & -769.451 & -9214.460 & 1728888.089 \\
\hline
\end{tabular}

- Teaching Evaluation and Analysis

Teaching and scientific evaluation analysis shows (Table 4) only the overall efficiency in 2001 and 2002 (TE = 1) is invalid and the overall efficiency (TE) from 2003 to 2010 is 1 , indicating that universities in Beijing gradually get rid of the effects of enrollment increase after several years of adjustment of resource allocation, and teaching and research are in DEA effective state, that is the output achieves the maximum in the case of minimum input. So seen just from the teaching perspective, are all these years in the most efficient state? In order to understand the teaching efficiency in these years, teaching indicators from 2000 to 2010 are re-selected for further analysis. Index system is shown in Table 6 , and the analysis results are shown in Table 7. 
TABLE VI. INDEX SySTEM OF TEACHING RESOURCES IN UNIVERSITIES OF BEIJING

\begin{tabular}{cc}
\hline Input Indicators (X) & $\begin{array}{c}\text { Average Students That a Full-time } \\
\text { Teacher is Responsible for (person)X1 }\end{array}$ \\
\cline { 2 - 2 } & \begin{tabular}{c} 
School Building Area (square meters)X2 \\
\cline { 2 - 2 }
\end{tabular} \\
\cline { 2 - 2 } & Books (ten thousand) \\
Output Indicators (Y) & Total Education IncomeX4 \\
\hline & Students in General University (per- \\
\end{tabular}

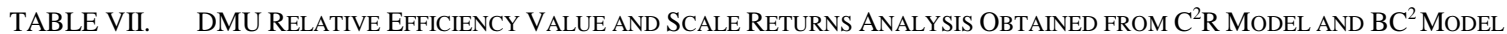

\begin{tabular}{|c|c|c|c|c|c|c|c|c|c|c|c|}
\hline DMU & 1 & 2 & 3 & 4 & 5 & 6 & 7 & 8 & 9 & 10 & 11 \\
\hline Year & 2000 & 2001 & 2002 & 2003 & 2004 & 2005 & 2006 & 2007 & 2008 & 2009 & 2010 \\
\hline $\begin{array}{r}C^{2} \boldsymbol{R} \text { Overall } \\
\text { Efficiency TE }\end{array}$ & 0.918 & 0.914 & 0.972 & 1.000 & 1.000 & 1.000 & 1.000 & 1.000 & 0.984 & 0.975 & 0.972 \\
\hline $\begin{array}{c}\boldsymbol{B C}^{2} \text { Overall } \\
\text { Efficiency TE }\end{array}$ & 0.918 & 0.914 & 0.972 & 1.000 & 1.000 & 1.000 & 1.000 & 1.000 & 0.984 & 0.975 & 0.972 \\
\hline $\begin{array}{l}\text { Pure Technical } \\
\text { Efficiency PTE }\end{array}$ & 1.000 & 1.000 & 1.000 & 1.000 & 1.000 & 1.000 & 1.000 & 1.000 & 1.000 & 1.000 & 1.000 \\
\hline $\begin{array}{l}\text { Scale Efficien- } \\
\text { cy SE } \\
\end{array}$ & 0.918 & 0.914 & 0.972 & 1.000 & 1.000 & 1.000 & 1.000 & 1.000 & 0.984 & 0.975 & 0.972 \\
\hline $\begin{array}{l}\text { Returns to } \\
\text { Scale RTS }\end{array}$ & $\begin{array}{c}\text { irs } \\
\text { Increas- } \\
\text { ing }\end{array}$ & $\begin{array}{c}\text { irs } \\
\text { Increas- } \\
\text { ing }\end{array}$ & $\begin{array}{c}\text { irs } \\
\text { Increas- } \\
\text { ing }\end{array}$ & $\begin{array}{c}- \\
\text { Constant }\end{array}$ & $\begin{array}{c}- \\
\text { Constant }\end{array}$ & $\begin{array}{c}- \\
\text { Constant }\end{array}$ & $\begin{array}{c}- \\
\text { Constant }\end{array}$ & $\begin{array}{c}- \\
\text { Constant }\end{array}$ & $\begin{array}{c}\text { drs } \\
\text { Decreas- } \\
\text { ing }\end{array}$ & $\begin{array}{c}\text { drs } \\
\text { Decreas- } \\
\text { ing }\end{array}$ & $\begin{array}{c}\text { drs } \\
\text { Decreas- } \\
\text { ing }\end{array}$ \\
\hline $\begin{array}{c}\text { Effectiveness } \\
\text { of Overall } \\
\text { Efficiency }\end{array}$ & $\begin{array}{l}\text { Non- } \\
\text { DEA } \\
\text { Effec- } \\
\text { tiveness }\end{array}$ & $\begin{array}{l}\text { Non- } \\
\text { DEA } \\
\text { Effec- } \\
\text { tiveness }\end{array}$ & $\begin{array}{l}\text { Non- } \\
\text { DEA } \\
\text { Effec- } \\
\text { tiveness }\end{array}$ & $\begin{array}{l}\text { DEA } \\
\text { Effec- } \\
\text { tiveness }\end{array}$ & $\begin{array}{l}\text { DEA } \\
\text { Effec- } \\
\text { tiveness }\end{array}$ & $\begin{array}{l}\text { DEA } \\
\text { Effec- } \\
\text { tiveness }\end{array}$ & $\begin{array}{l}\text { DEA } \\
\text { Effec- } \\
\text { tiveness }\end{array}$ & $\begin{array}{l}\text { DEA } \\
\text { Effec- } \\
\text { tiveness }\end{array}$ & $\begin{array}{l}\text { Non- } \\
\text { DEA } \\
\text { Effec- } \\
\text { tiveness }\end{array}$ & $\begin{array}{l}\text { Non- } \\
\text { DEA } \\
\text { Effec- } \\
\text { tiveness }\end{array}$ & $\begin{array}{l}\text { Non- } \\
\text { DEA } \\
\text { Effec- } \\
\text { tiveness }\end{array}$ \\
\hline
\end{tabular}

As can be seen from the results shown in Table 7, although the comprehensive evaluation analysis of teaching and research after 2003 has reached the optimum, the analysis from the perspective of education index is not the case. The overall efficiency of 2003-2007 (TE) is 1 and input-output DEA is effective, indicating that the teaching of these years has achieved good scale merit. But the overall efficiency of 2007-2010 is less than 1. Among the years of which the overall efficiency is less than 1 , the scale merit during $2000-2003$ is increasing while the scale merit during 2008-2010 is decreasing.

Comparing the analysis results in Table 4 and Table 7 , after college enrollment increase in 1999, insufficient resources in teaching first appeared in 2000, so the teaching resources need to be increased and the scale should be enlarged (scale efficiency SE <1, returns to scale RTS is increasing, Table 4). Then teaching and research in 2001 and 2002 showed the same situation, that is, the overall efficiency is less than 1 , DEA is invalid, scale efficiency SE $<1$, and RTS is increasing (Table 7). It shows that, in addition to the lack of teaching resources in recent years and the need to increase investment to expand scale, in the aspect of scientific research, it is required to continue to expand the scale and make full use of resources, to improve research efficiency. After years of efforts, the overall efficiency of teaching and research during 2003-2007 has reached 1, which means the output reaches the maximum in the case of the minimum input, and the use efficiency of resource allocation reaches the optimum. But the teaching and research scale of these years should not be expanded, but be maintained in the current modest size (the technical efficiency is 1 , and returns to scale are constant). However, the overall efficiency of 2008-2010 in teaching evaluation is less than 1 , returns to scale are decreasing (Table 7 ), but the pure technical efficiency is 1 , and the problem obviously lies in that scale expansion causes diseconomies of scale.

\section{CONCLUSIONS}

After the national undergraduate enrollment increase in 1999 , the consequences are reflected immediately in the teaching and research of Beijing in 2000, but are reflected in 2001 and 2002. It indicates that invalid overall efficiency appears in the universities of Beijing after college enrollment expansion. But returns to scale are increasing, demonstrating that if the investment in various aspects can be properly regulated, output of research and teaching can increase. After 2003, with the improvement of supporting investment of all aspects, it gradually moves into the normal stage of development. But after 2008 , there is a surplus of scale in the teaching evaluation,

The research results above show that the change in college enrollment will cause some effects on the teaching and research of universities, and these effects may appear in the future two to three years. Colleges can adjust the distribution of input resources and enlarge scale to increase output, and further enhance the DEA effectiveness of education resource allocation. However, we cannot blindly expand the scale, otherwise the scale efficiency would be invalid again, and the resources cannot be made full use.

Efficiency of universities is volatile, especially teaching efficiency. We should not be optimistic blindly. Universities should establish a reasonable evaluation system, to dynamically evaluate the efficiency of universities, prevent the waste of resources and the overlarge size of scale, promote the sus- 
tained and stable development of teaching and research in universities, and improve efficiency.

\section{REFERENCES}

[1] M. Tang, "On Several Issues of Enrollment Increase", Peking University Education Review, Beijing, vol. 2, pp. 62-71+190, 2006.

[2] R. W. Hu, "Report on China Education and Human Resource Issues", Exploring Education Development, Shanghai, vol. Z1, pp. 1, 2003.

[3] Y.B. Li, "Higher Education Development and College Mission", Journal of Sun Yat-sen University (Social Science Edition), Guangzhou, vol. 5, pp. 1-5+123, 2005.

[4] C. L. Li, "Analysis on the Employment Status and Influencing Factors of College Graduates of the Generation after 80s - Survey Based on the Graduates from 6 Universities of 985 Project”, Jiangsu Social Sciences, Nanjing, vol. 3, pp. 45-53, 2012.

[5] H. Y. Yu, and D. Chen, "College Enrolments Increase, Difficult Employment of Graduates and "High Consumption of Talents" ", Social Science Research, Chengdu, vol. 3, pp. 47-52, 2006.

[6] Y. Q. Wu, "Enrolments Expansion of Higher Education in China and Analysis on Its Influence on Graduates Employment", Northwest Population, Lanzhou, vol. 1, pp. 20-23, 2007.

[7] L. M. Zhang, "University Enrolments Increase and Graduates Employment", China Adult Education, Jinan, vol. 22, pp. 59-60, 2008.

[8] Y. Wu, F. H. Huang, and W. Xiong, "Causes and Countermeasures of Difficult Employment of College Graduates Under the Background of College Enrolments Increase ", Journal of Nanchang College of Education, Nanchang, vol. 4, pp. 31-33, 2008.

[9] W. R. Jia, "Causes and Countermeasures of Difficult Employment of College Graduates Under the Background of Higher Education Popularization", Science and Technology Information, Jinan, vol. 35, pp. $335+345,2008$.

[10] W. Liu, and L. Q. Zhou, "Difficult Employment of College Graduates Caused by Employment Increase", Journal of Technology College Education, Wuhan, vol. 1, pp. 41-44, 2005.

[11] K. G. Fu, "How does University Help Graduates Solve Difficulty in Employment", Newsdom, Changsha, vol. 7, pp. 64+53, 2003.

[12] W. Fan, "Analysis and Thinking on the Difficult Employment of College Graduates", Pioneering with Science \& Technology Monthly, Wuhan, vol. 4, pp. 108-109, 2010.

[13] Q. Wu, "Study on Difficult Employment of Graduates in Local Universities", Education Exploration, Harbin, vol. 6, pp. 145-147, 2010.

[14] Z. Z. Han, and L. B. Si, "Cost - benefit Analysis on College Enrolments Increase Policy Journal of Jiangsu University (Higher Education Study Edition)", Zhenjiang, vol. 3, pp. 42009, 2006.
[15] W. L. Wang, "Study on Higher Education Development of China after Enrollment Increase Times", Modern Education Science, Changchun, vol. 9, pp. 55-59, 2011.

[16] L. Zhang, and M. K. Yang, "Rational Thinking on the Development Scale of Higher Education and Social and Economic Benefits", Modern Education Management, Shenyang, vol. 2, pp. 36-39, 2009.

[17] G. S. Lu, and L. Liu, "Study on the Research Efficiency and Development Trend of Universities Directly Under the Ministry of Education during 2000 - 2004 - Application of DEA Method", University (Research and Evaluation), Beijing, vol. 5, pp. 24-31, 2007.

[18] B. Xu, D. W. Zhang, J. J. Wu, Jiejun, and H. F. Xue, "Assessment and Application of Running Efficiency of Universities Based on DEA Model ", Computer Simulation, Beijing, vol. 10, pp. 284-286+307, 2008.

[19] Levin, H. M., "Measuring efficiency in educational production", Public Finance Quarterly, vol. 2, pp. 42087, 1974.

[20] Bessent, A. M. , Bessent, E. W. , Charnes, A. , Cooper, W. W. , and Thorogood, N. C. ,"Evaluation of education of educational program proposals by means of DEA", Educational Administration Quarterly, vol. 19, pp. 82-107, 1983

[21] Abbotta, M., and Doucouliagosa, C., "The efficiency of Australian universities:A data envelopment analysis", Economics of Education Review, vol. 22, pp. 89-97, 2003.

[22] Flegg, A. T., Allen, D. O., Field, K., and Thurlow. T. W., "Flegg,A.T. , Allen,D.O., Field, K.,\& Thurlow.T.W. Measuring the efficiency of British universities: A Multi-period data envelopment analysis", Education Economics, vol. 12, pp. 231-249, 2004.

[23] G. Li, and W. Li, "The Evaluation of $\mathrm{C}^{2} \mathrm{GS}^{2}$ Models Based on Output on Study Achievement (Effect)", Education Economics, Beijing, vol. 18, pp. 59-64, 2008.

[24] Charnes A, Cooper W W, Rhodes E, "Measuring the efficiency of DMU”, European Journal of Operational Research, vol. 2, pp. 429-444, 1978.

[25] S. Y. Wang, L. Y. Liu, S. M. Zhang, "Evaluation Study on the Sustainable Development Ability in Inner Mongolia District Based on DEA Method ", Anhui Agricultural Sciences, Hefei, vol. 19, pp. 9150-9152, 2009.

[26] Z. Zhao, "Evaluation Analysis on Technology Resource Allocation Efficiency of Higher Education Based on DEA - Taking Heilongjiang Province as an Example ", Science \& Technology Progress and Policy, Wuhan vol. 2, pp. 112-115, 2009.

[27] Z. H. Sheng, Q. Zhu, and G. M. Wu, DEA Theory, Method and Application, 1rd ed., Science Press: Beijing, 1996. 